\title{
OBESITY AND SMOKING HABITS BY SOCIAL CLASS
}

\author{
T. KHOSLA* AND C. R. LOWE** \\ Welsh National School of Medicine, Cardiff
}

In a recent paper we reported that there are considerable differences in the body weights of men categorized by their smoking habits (Khosla and Lowe, 1971). In a population of 10,482 steel workers we found that the men who had never smoked were much heavier than the smokers and that the men who had given up smoking for eight or more years were almost as heavy as those who had never smoked. The difference between the weights of non-smokers and smokers increased with age to the extent that over 40 years of age it was about $13 \mathrm{lb}(5.9 \mathrm{~kg})$.

Our findings are in general agreement with two earlier surveys reported in the literature. In a largescale study of coal workers at three Scottish collieries, Ashford and his co-workers (1961) found that non-smokers were consistently heavier than smokers at each of six age groups, and at 40 years of age or over the difference was about $10 \mathrm{lb}(4 \cdot 5 \mathrm{~kg})$. A survey of 8,548 Norwegian seamen and 9,114 men ashore (Natvig and Vellar, 1965) showed similar body weight differences in relation to smoking habits in the middle-age groups.

However, Waller and Brooks (1972) found little difference between the body weights of non-smokers and smokers, surveyed while attending a public health exhibition in the city of London, and Pincherle (1971) has published a table showing four broad weight groupings (expressed as a percentage of average weight for age and height, calculated from the Metropolitan Insurance Company data) for the members of the Institute of Directors with the comment that the weight distributions could not be discriminated according to smoking habits. Because the Institute members are all from social classes I and II, it was suggested that the disagreement with our own findings might be attributable to differences in the trends of obesity and smoking habits according to social class. This is a point of some importance, for $78 \%$ of men in our study were drawn from social classes III and IV. In this paper, therefore, we examine our data on the weights of the steel workers in relation to their social class as well as to their age and smoking habits.

\footnotetext{
-Department of Medical Statistics

* Department of Social and Occupational Medicine
}

\section{Data AND Methods}

A full description of the methods by which the information was collected has been given elsewhere (Lowe et al., 1968). Here it is sufficient to mention that the men had their standing heights measured without shoes and were weighed in indoor clothes without shoes or jackets (for purposes of comparison with other studies, the weight of indoor clothes may be taken as about $5 \mathrm{lb}$ or $2 \cdot 3 \mathrm{~kg}$ ). The occupations of the steel workers were recorded at the time of interview and have been transformed to the appropriate social class groups according to the Registrar General's classification. In this report we include data on the men surveyed at both Port Talbot and Ebbw Vale steel works, 17,836 men in all. The data from the two works have been combined as the trends they displayed were similar.

\section{RESULTS}

About $57 \%$ of the steel workers were classified as social class III, so we have divided this large group into two subgroups of non-manual and manual workers according to the classification based on the socio-economic grouping (SEG) of the Registrar General (1970) (non-manual: SEG, 5, 6, 7; manual: SEG, 8, 9). There is good agreement between the classification of occupations based on the socioeconomic grouping and the steel workers' own independent evaluation of the physical nature of their jobs (Table I).

TABLE I

PHYSICAL DEMANDS OF WORK AND SOCIO-ECONOMIC GROUPINGS IN SOCIAL CLASS III (PORT TALBOT AND EBBW VALE STEEL WORKERS 1964-65)

\begin{tabular}{|c|c|c|c|c|}
\hline \multirow{2}{*}{\multicolumn{2}{|c|}{$\begin{array}{l}\text { Physical Demands } \\
\text { of Job }\end{array}$}} & \multicolumn{3}{|c|}{$\%$ Distribution } \\
\hline & & SEG $5,6,7$ & SEG 8, 9 & Total \\
\hline $\begin{array}{l}\text { Heavy or moderate } \\
\text { Light or sedentary }\end{array}$ & $\cdots$ & $\begin{array}{r}5 \cdot 2 \\
94 \cdot 8\end{array}$ & $\begin{array}{l}66 \cdot 0 \\
34 \cdot 0\end{array}$ & $\begin{array}{l}59 \cdot 0 \\
41 \cdot 0\end{array}$ \\
\hline Total & . & $\begin{array}{l}100 \\
(1,199)^{*}\end{array}$ & $\begin{array}{l}100 \\
(8,907)\end{array}$ & 100 \\
\hline
\end{tabular}

*No. of men 
TABLE II

SOCIAL CLASS DISTRIBUTION OF STEEL WORKERS (PORT TALBOT AND EBBW VALE)

\begin{tabular}{|c|c|c|c|c|c|c|}
\hline \multirow[b]{3}{*}{ Survey } & \multicolumn{6}{|c|}{$\%$ Distribution } \\
\hline & \multicolumn{6}{|c|}{ Social Class } \\
\hline & $\begin{array}{l}\text { I \& II } \\
\text { Non- }\end{array}$ & $\underset{\text { III }}{\text { anual }}$ & III & $\underset{\text { Manua }}{\text { IV }}$ & V & $\underset{\text { Classes }}{\text { All }}$ \\
\hline $\begin{array}{l}\text { Steel workers } \\
1964-65\end{array}$ & $6 \cdot 6$ & $6 \cdot 6$ & $50 \cdot 0$ & $21 \cdot 7$ & $15 \cdot 2$ & $\begin{array}{c}100 \\
(17,836)\end{array}$ \\
\hline $\begin{array}{l}\text { United Kingdom } \\
\text { (1965) }\end{array}$ & $15 \cdot 4$ & 58 & & $17 \cdot 4$ & $8 \cdot 7$ & 100 \\
\hline
\end{tabular}

TABLE III

PERCENTAGE OF CURRENT SMOKERS BY SOCIAL CLASS

\begin{tabular}{|c|c|c|c|c|c|c|}
\hline \multirow[b]{2}{*}{ Survey } & \multicolumn{6}{|c|}{ Social Class } \\
\hline & $\begin{array}{l}\text { I \& II } \\
\text { Non- }\end{array}$ & $\begin{array}{l}\text { III } \\
\text { inua }\end{array}$ & III & $\underset{\text { Manual }}{\text { IV }}$ & V & $\begin{array}{c}\text { All } \\
\text { Classes }\end{array}$ \\
\hline \multirow{2}{*}{$\begin{array}{l}\text { Steel workers } \\
\text { United Kingdom } \\
\text { (1965) }\end{array}$} & 59 & 57 & 65 & 68 & 71 & 65 \\
\hline & 63 & & & 71 & 73 & 67 \\
\hline
\end{tabular}

\section{Social Class Differences in Smoking Habits}

Table II gives the social class distribution of the steel workers surveyed at Port Talbot and Ebbw Vale, and Table III gives the percentage of current smokers within each of the classes. For comparison, the corresponding percentages are also given from the general population in the United Kingdom as estimated by the Tobacco Research Council (Todd, 1969). It will be seen that the steel workers are under-represented in social classes I and II, and correspondingly over-represented in classes IV and $V$. This is to be expected because of the nature of the various manual occupations in a large steel works. There is good agreement with the national data on the trend of an increase in proportion of smokers with the decline in social class, although within each class there are fewer smokers among the steel workers than among the general population.

Smoking habits vary with age as well as with social class (Appendix A). The lower social classes tend to acquire the smoking habit at an earlier age; for example, at ages $20-24,41 \%$ of the non-manual workers from social class III had never smoked compared with only $21 \%$ from social class $\mathrm{V}$ and there are consistently fewer smokers among the non-manual workers, age for age, than among the manual workers.

The overall percentages of smoking habits at all ages within the social classes are not comparable because of the varying age distribution of the 15 subgroups (5 social groups and 3 smoking classes), so a statistical method of standardization for age has

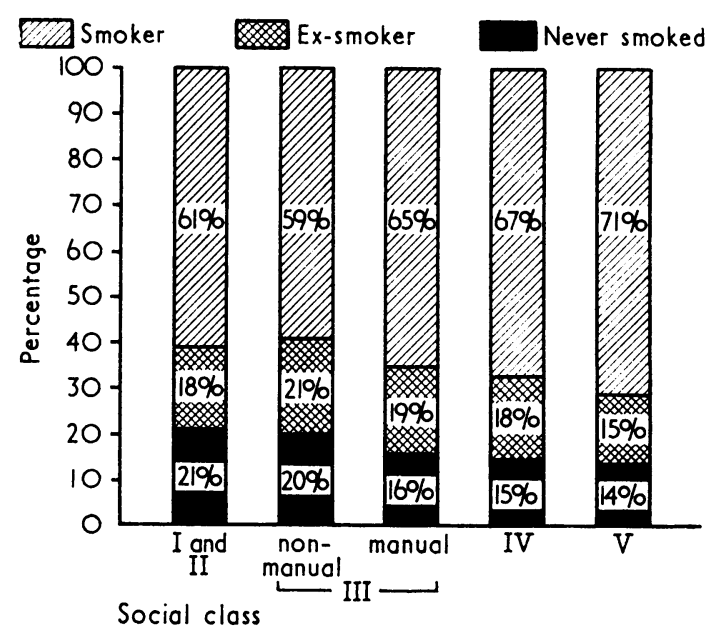

Fig. 1. Smoking habits by social class (standardized for age) Port Talbot and Ebbw Vale steel workers 1964-65.

been adopted. The percentages entered in the last column of the table (Appendix A) are derived by $\frac{\Phi}{3}$ uniform weighting of the age-specific percentages with the overall age distribution (similar to the calculation of a standardized mortality rate). Tre age-standardized percentage of current smokezs! increases and of non-smokers decreases with desce of the social class scale (Figure 1).

\section{Social Class Differences in Body Weight}

The mean body weights adjusted to a height of $\stackrel{\mathbb{Q}}{\propto}$ 68 inches $(1.7 \mathrm{~m}$ ) (for the method of adjustment see $\overrightarrow{\vec{A}}$ Khosla and Lowe, 1967) show that for every social $\frac{\text { 의 }}{3}$ class and age group (with one unimportant exception) the non-smokers are always heavier than the smokers? (Appendix B). This fact is illustrated in Figure 2. $\frac{\overline{\mathrm{C}}}{3}$

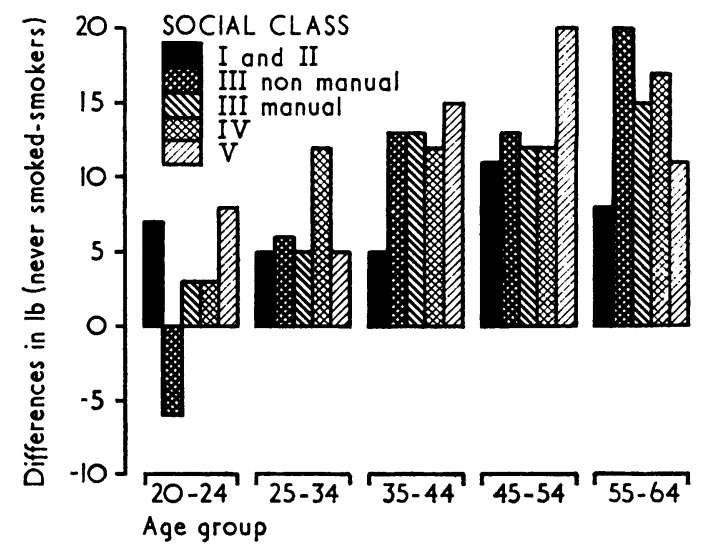

FIG. 2. Difference in body weight between men who have never smoked and smokers by social class and age. 


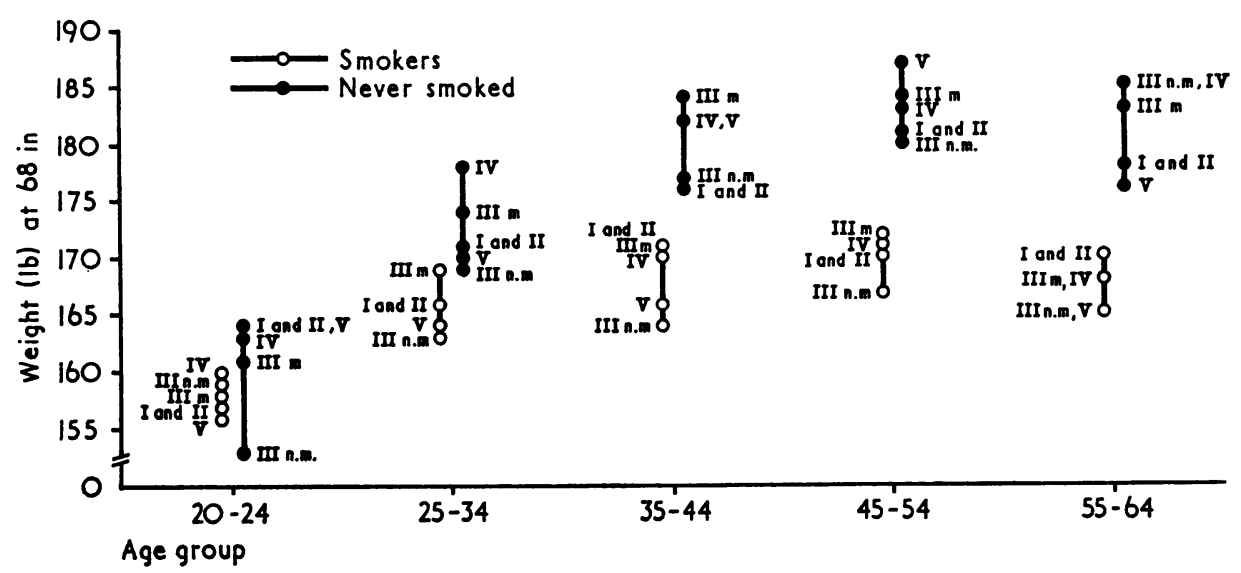

Fro. 3. Range of mean body weights at 68 inches between the social classes by smoking habit and age.

The differences tend to increase with age, and for several of the social class subgroups of men aged over 45 , non-smokers are $15 \mathrm{lb}(6.8 \mathrm{~kg})$ or more heavier than smokers.

Within age and smoking categories there are marked differences between the estimated body weights of the social classes (Figure 3). The range of variation between the social classes is greater among the never-smoked group than among the smokers in every age group. At ages 35 and over, the subgroups by social class of men who have never smoked are well discriminated from the subgroups of current smokers, so that, ignoring social class, the lightest of the non-smoker subgroups is always heavier than the heaviest of the smoker subgroups. For example, at ages 45-54, the lightest non-smoking subgroup (III non-manual) is $8 \mathrm{lb}(3.6 \mathrm{~kg})$ heavier than the heaviest subgroup of smokers (III manual) and the difference between the two extreme subgroups is 20 lb $(9.0 \mathrm{~kg}$ ) (III non-manual smoker and $\mathrm{V}$ never smoked).

The age-standardized body weights at 68 inches $(1 \cdot 7 \mathrm{~m})$ (Figure 4$)$ show that the never-smoked categories of social classes III manual, IV, and V are about $5 \mathrm{lb}(2 \cdot 3 \mathrm{~kg})$ heavier than the corresponding groups of social classes I, II, and III non-manual. The trend displayed by the smokers, however, is erratic with no clear indication that the non-manual social classes are different in weight from the manual social classes. On average, the smokers from social classes I and II are as heavy as smokers from social class IV and the non-manual smokers from class III weigh as much as smokers from class $\mathrm{V}$.

\section{Discussion}

Our findings that the lower social classes tend to smoke more (Figure 1) are in general agreement with the trends reported in the literature. Ashford and his co-workers (1961) found that there were $80 \%$ of smokers among coal workers at three Scottish collieries. In contrast, only $47 \%$ of the Institute of Directors members are reported to be smokers (Pincherle, 1971). A great change in smoking habits has been observed among doctors between 1951 and 1966 - the percentage of smokers decreased from 66 to 49. The graduate staff of the University of Edinburgh has also shown a marked reduction in current smoking habits (Royal College of Physicians, 1971).

A consistent difference is observed between the non-manual and manual groups from social class III in their smoking habits. In every age group there are more smokers among the manual workers and the

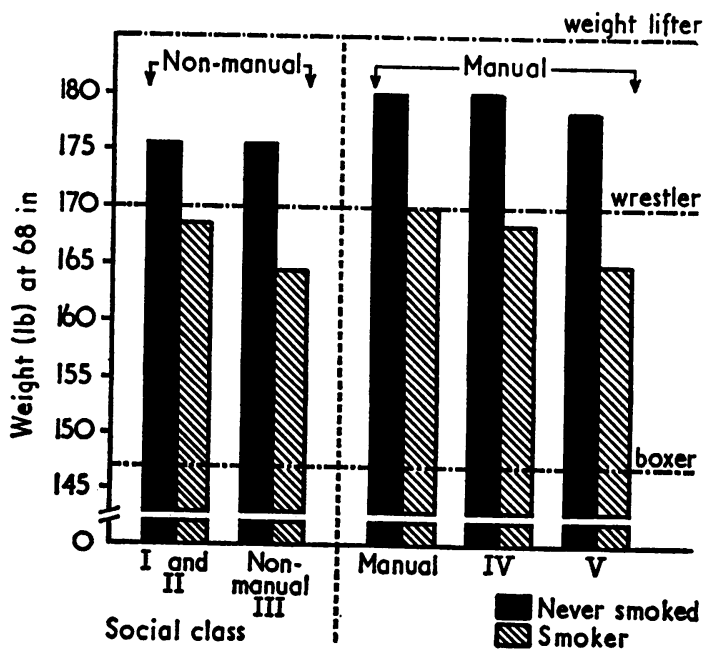

FIo. 4. Body weight at 68 inches (standardized for age) by social class and smoking group. 
difference is very marked at the younger ages (Figure 5). Consistent weight differences are also observed by smoking habits (Figure 6). At ages 40 or above the never-smoked groups are $12 \mathrm{lb}(5.4 \mathrm{~kg})$ or more heavier than the smokers within both nonmanual and manual groups, and within the smoking groups the manual workers are considerably heavier than the non-manual groups at most ages.

Obesity implies an excessive amount of body fat. The criterion of over-weightness, however, does not necessarily imply obesity. Certain groups (wrestlers and weightlifters) are overweight because of muscular development. Although we have no direct evidence (skinfold measurements were not taken) that our steel workers are obese rather than muscular, a comparison of their body weights with certain groups of sportsmen is of interest. Light-welter-weight boxers are about 68 inches $(1.7 \mathrm{~m})$ tall and weigh $147 \mathrm{lb}$ $(66.7 \mathrm{~kg})$. Welter-weight wrestlers are about the

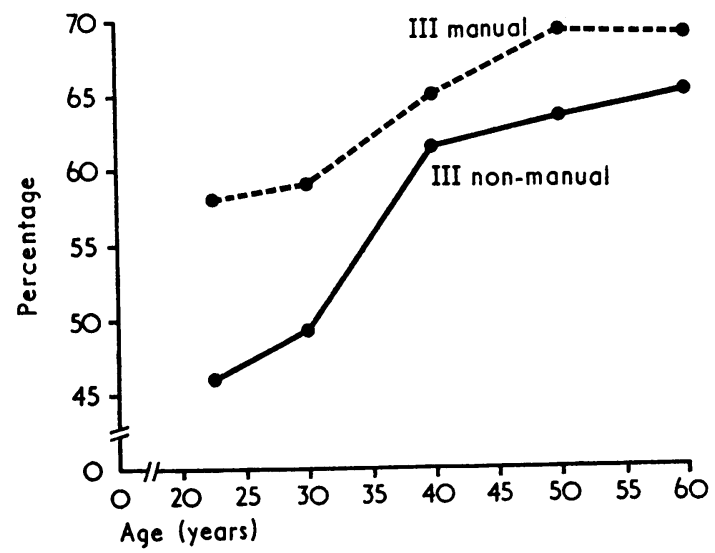

Fio. 5. Percentage of current smokers in the manual and non-manual occupational subgroups of social class III.

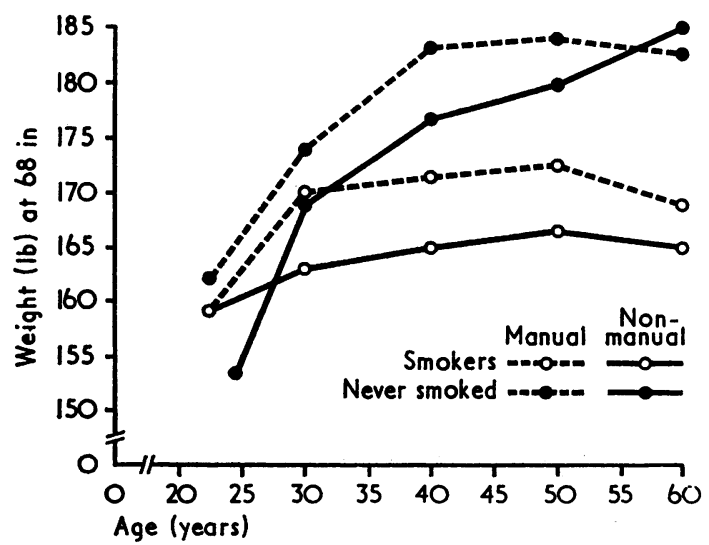

Fio. 6. Comparison of body weights (lb) at 68 inches between manual and non-manual occupations of social class III. same height but weigh $170 \mathrm{lb}(77 \cdot 1 \mathrm{~kg})$ and lightheavy-weight weight-lifters weigh about $186 \mathrm{lb}(84 \cdot 4$ $\mathrm{kg}$ ) (Khosla, 1968). Our group of smokers are about $18 \mathrm{lb}(8 \cdot 2 \mathrm{~kg})$ heavier than the boxers and approach the body weights of wrestlers (Figure 4). The weights of our non-smoking groups exceed the weight of wrestlers and approach the weight of weight-lifters. If our steel workers are not obese, then they must have the physique of wrestlers.

Men who have never smoked have been found to be heavier than smokers in Norway (Natvig and Vellar, 1965), in Scottish collieries (Ashford et al., 1961), and now in our large population of steel workers at Port Talbot and Ebbw Vale. In another study, reported recently from Norway (Bjelke, 1971), non-smoking men were only slightly heavier than smokers, but non-smoking women were about $10 \mathrm{lb}$ $(4 \cdot 5 \mathrm{~kg})$ heavier in some elderly age groups.

Apart from marked differences between the body weights of non-manual and manual workers from social class III (Figure 6) there is no social class trend in the body weight of current smokers (Figure 4); the body weight of the never-smoked group, however, tends to increase with lower social class. As a consequence the difference between the bodso weight of smokers and non-smokers also tends to increase with lower social class. There are fewe smokers in the higher social classes (Figure 1) and those who do not smoke are on average lighter than the corresponding groups of the lower social classes (Figure 4).

Pincherle (1971) was unable to differentiate the members of the Institute of Directors by their smoking habits. In another report on the Institute members (Richardson and Pincherle, 1969) the overall estimated weight at 68 inches $(1.7 \mathrm{~m})$ was given as $170 \mathrm{lb}(77 \cdot 1 \mathrm{~kg})$. It follows that the directors who smoke are about the same weight as the steel workers who smoke, but the non-smoking directors are considerably lighter than the corresponding groups from the steel industry. Pincherle's analysis (1971) on the smoking groups was based on four very broad weight groupings, and his table reveals significantly higher percentages of 'underweights' in smokers $(13 \%)$ than in non-smokers $(7 \%)$. Waller and Brooks (1972) were also unable to find any substantial difference between the body weights of smokers and non-smokers among men attending a health exhibition during the lunch hour in London. Their sample contained an even higher proportion of non-smokers than among the steel workers of social classes I and II. The possibility of bias in favour of attracting health conscious people and non-manual workers to an exhibition entitled 'Good Health' is, we feel, a strong one, particularly so far as the 
TABLE IV

BODY WEIGHT AT 68 in (173 cm) BY TYPE OF TOBACCO* SMOKED

AGE 20-64

\begin{tabular}{|c|c|c|c|c|}
\hline & & $\begin{array}{l}\text { Never } \\
\text { Smoked }\end{array}$ & $\begin{array}{c}\text { Smokers of } \\
\text { Cigarettes }\end{array}$ & $\begin{array}{c}\text { Smokers of } \\
\text { Pipes or } \\
\text { Cigars only }\end{array}$ \\
\hline \multicolumn{2}{|c|}{$\begin{array}{lll}\text { Weight (lb) } & \ldots & \ldots \\
\text { Age (yr) } & \text {. } & \text {. } \\
\text { Cigarettes equivalent } & \text { per }\end{array}$} & $\begin{array}{l}176 \\
37 \cdot 6\end{array}$ & $\begin{array}{r}167 \\
42 \cdot 4\end{array}$ & $\begin{array}{r}176 \\
47 \cdot 8\end{array}$ \\
\hline $\begin{array}{l}\text { day } \\
\text { Number }\end{array}$ & $\begin{array}{ll}\cdots & \cdots \\
\cdots & \cdots\end{array}$ & 2,864 & $10,542^{18 \cdot 4}$ & ${ }_{897}^{11 \cdot 2}$ \\
\hline
\end{tabular}

*Smokers of mixed tobacco are excluded.

representation of the non-smoking group is concerned. At ages 45 and over, their smokers are only about $6.5 \mathrm{lb}(3 \mathrm{~kg})$ lighter than our smokers but their non-smokers are considerably lighter than our non-smokers $(15 \cdot 4 \mathrm{lb}$ or $7 \mathrm{~kg})$.

The finding that there is little difference between the body weight of smokers in the different social classes, but that non-smokers from the lower social classes are much more obese than non-smokers of higher social class, is interesting. In part, it may be due to a greater awareness of the health hazards of smoking and of obesity among the more educated. There are certainly fewer smokers among the higher social classes, and a greater proportion of them are pipe and cigar smokers (relative to the lower social classes). We also find it interesting that smokers of pipes and cigars are as obese as non-smokers (Table IV). This finding is in agreement with that of Ashford and his co-workers (1961). Our pipe and cigar smokers are $9 \mathrm{lb}(4 \cdot 1 \mathrm{~kg})$ heavier than smokers of cigarettes only, and they equal the body weight of the never-smoked category. In the middle-age groups there is little variation in the trend of weight with age, and the effect of adjustment for age differences is small. In terms of quantity of tobacco smoked, however, there is a substantial difference between the

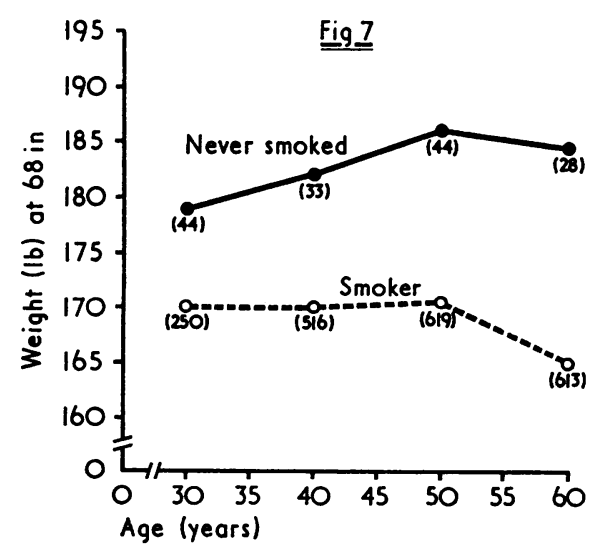

Fig. 7. Body weight (lb) at 68 inches of chronic bronchitics by age and smoking habit. (Numbers of men are shown in parentheses). two types of smokers. Pipe and cigar smokers smoke less tobacco than smokers of cigarettes only. Because of small numbers in our higher social classes, it has not been possible for us to compare the obesity of smokers from the different social classes according to the type of tobacco consumed.

Longitudinal studies on ex-smokers by Brozek and Keys (1957) revealed an increase of about $8 \mathrm{lb} \mathrm{(3.6}$ $\mathrm{kg}$ ) in weight during a three-year period in comparison with a control group of cigarette smokers, who registered a fall of $1 \mathrm{lb}(0.45 \mathrm{~kg})$ over the same period. They point out ..... that experiments demonstrating inhibition of hunger contractions by smoking and increased tobacco consumption by people on a reduced diet suggest that smoking tends to depress the appetite for food. It is also possible that some psychogenic smokers become psychogenic eaters instead'.

In view of the marked difference between the body weights of non-smokers and smokers, it is of interest to examine the extent to which that difference is maintained within subgroups categorized by their respiratory symptomatology. Chronic bronchitis can be defined in terms of the MRC questionnaire on respiratory symptoms (Medical Research Council, 1960) as persistent cough and phlegm with one or more of the following complications: a period of increased cough and phlegm lasting for three or more weeks in the past three years; a chest illness which has resulted in absence from work for one or more weeks in the past three years; shortness of breath when walking with other people at an ordinary pace on the level. In our survey, among the men with chronic bronchitis defined in this way, the non-smokers were much heavier than the smokers for every age group (Figure 7). Among the men with neither simple nor chronic bronchitis (i.e., without

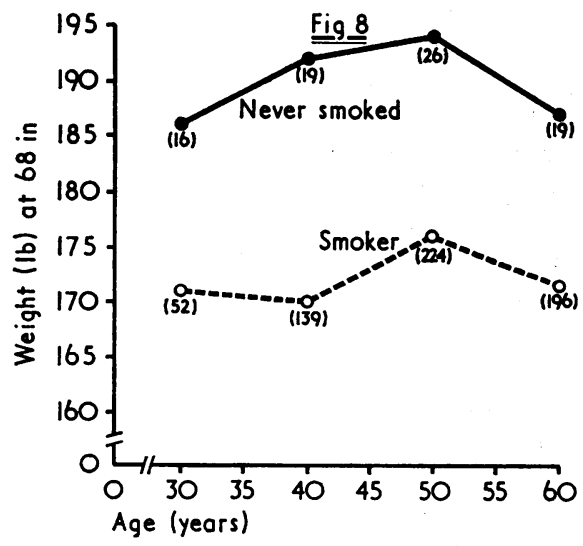

FIG. 8. Body weight (lb) at 68 inches of non-bronchitics complaining of dyspnoea by age and smoking habit. (Numbers of men are shown in parentheses). 
persistent cough and phlegm), the difference between the weights of non-smokers and smokers was even greater and approached $20 \mathrm{lb}(9 \cdot 1 \mathrm{~kg})$ (Figure 8). These findings suggest that although the breathlessness of bronchitic smokers is probably due in large part to impairment of lung function, among the non-smokers it is more likely to be due to gross obesity.

Marked differences in the body weights of men have been reported in periods of economic depression. During the 1930s in Britain, the unemployed were consistently lighter, and in some elderly age groups the difference was about $10 \mathrm{lb}$ $(4.5 \mathrm{~kg})$ (Cathcart, Hughes and Chalmers, 1935). Large differences are still observed in underprivileged countries. Underwood and his co-workers (1967) found that high income groups in West Pakistan were $8 \mathrm{lb}(3.6 \mathrm{~kg})$ heavier (adjusted for height) than the lower income groups in the age range 23-35 years, while in the younger age group (15-21 years) the difference exceeded $10 \mathrm{lb}(4 \cdot 5 \mathrm{~kg})$. And indeed Clements and Pickett (1954) pointed out that in Britain in 1883 men in social classes $I$ and II at ages $30-39$ were $8 \mathrm{lb}(3.6 \mathrm{~kg})$ heavier than men in social class III. This social class difference was no more than about $4 \mathrm{lb}(1.8 \mathrm{~kg})$ among Scotsmen measured in 1941 (Clements and Pickett, 1954). In Britain the opposite now appears to be true-men in the lower social classes are heavier, height for height, than men in the higher social classes. In an earlier study (Khosla and Lowe, 1967) we were unable to show any difference in the body weights (adjusted for height) of men employed by a large electrical engineering firm in Birmingham (surveyed in 1960) categorized according to their mode of payment (monthly, weekly, and wage earners). The greater obesity of employed manual workers (smokers and non-smokers combined) is probably related to the affluence of post-war years and the increased mechanization of industry.

Many environmental and occupational factors contribute to the higher morbidity and mortality of manual workers. The observed trends of higher current smoking habits and higher obesity among non-smokers in the lower social classes would appear to impose additional health hazards on an already vulnerable group.

\section{SUMMARY}

The body weights of 17,836 men surveyed at both Port Talbot and Ebbw Vale steelworks are examined in relation to their social class, age, and smoking habits. Social class III is divided into subgroups of non-manual and manual workers. A consistent difference is observed between the subgroups of class III both in their smoking habits and in their body weights. There are more smokers among manual workers, and within the smoking categories the manual workers are considerably heavier than non-manual groups. At ages $\mathbf{4 0}$ or above, the neversmoked groups are $12 \mathrm{lb}(5.4 \mathrm{~kg})$ heavier than the smokers within both non-manual and manual groups. Social classes IV and V tend to acquire the smoking habit at an earlier age. At ages 20-24, $41 \%$ of the non-manual workers from social class III had never smoked compared with only $21 \%$ from social class $\mathrm{V}$.

The never-smoked categories are consistently heavier than smokers within every social class. There is no social class trend in the body weights of current smokers; the body weight of the never-smoked group, however, tends to increase in the lower social classes.

Many environmental and occupational factors are known to contribute to the higher morbidity and mortality of lower social classes. These vulnerable groups are now becoming increasingly exposed to the additional health hazards of higher smoking rates and greater obesity.

A generous grant from the Nuffield Foundation madeo this investigation possible. It is with pleasure that we acknowledge our indebtedness to Richard Thomas and Baldwins Limited and the Steel Company of Wales Limited for permission to carry out the investigation, and to their managements and the trades unions for their support while it was in progress. Finally, we wish to express our gratitude to Dr. J. Howlett and Mrs. J. Lay, of the Atlas Computer Laboratory, Chilton, Berks., for the invaluable help they and their staff gave us with the analysis of our data.

\section{REFERENCES}

AShFord, J. R., Brown, S., Duffield, D. P., SMtth, C. S., and FAY, J. W. J. (1961). The relation between smoking habits and physique, respiratory symptoms, ventilatory function, and radiological pneumoconiosis amongst coal workers at three Scottish collieries. Brit. J. prev. soc. Med., 15, 106.

BJELKE, E. (1971). Variation in height and weight in the Norwegian population. Brit. J. prev. soc. Med., 25, 192.

Brozex, T., and KeYs, A. (1957). Changes of body weight in normal men who stop smoking cigarettes. Science, 125,1203 . Quoted in leader on smoking and body weight. Lancet, 1957, 2, 282.

Cathcart, E. P., Hughes, D. E. R., and Chalmers, J. G. (1935). The physique of man in industry. Rep. industr. Hlth Res. Bd (Lond.). No. 71. H.M.S.O., London.

Clements, E. M. B., and Picketr, K. G. (1954). Body weight of men related to stature, age, and social status. Weight of Scotsmen measured in 1941. Brit. J. prev. soc. Med., 8, 99. 
Khosla, T. (1968). Unfairness of certain events in the Olympic Games. Brit. med. J., 4, 111.

-, and Lowe, C. R. (1967). Indices of obesity derived from body weight and height. Brit. J. prev. soc. Med., 21, 122.

and - (1971). Obesity and smoking habits. Brit. med. J., 4, 10.

Lowe, C. R., Pelmear, P. L., Campbell, H., Hitchens, R. A. N., Khosla, T., and King, T. G. (1968). Bronchitis in two integrated steel works. Ventilatory capacity, age, and physique of non-bronchitic men. Brit. J. prev. soc. Med., 22, 1.

Medical Research Council (1960). Standardized questionaries on respiratory symptoms. Brit. med. J., 2, 1665.

Natvig, H., and Vellar, O. D. (1965). Hoyde-og Vektunder-sokelser av Norske Sjomenn og Menn i Land. Forskningstres fra Landsforen.f. Kosth, og Helse. Melding 8, pp. 1-24, Oslo.

Pincherle, G. (1971). Obesity and smoking habits. Brit. med. J., 4, 298.
Registrar General (1970). Classification of Occupations 1970. Population Censuses and Surveys, H.M.S.O., London.

Richardson, J. F., and Pincherle, G. (1969). Heights and weights of British businessmen. Brit. J. prev. soc. Med., 23, 267.

Royal College of Physicians (1971). Smoking and Health Now. Pitman Medical and Scientific Publishing Co., London.

ToDD, G. F. (1969). Statistics of Smoking in the United Kingdom. Tobacco Research Council, Research Paper No. 1, 5th ed.

Underwood, B. A., Hepner, R., Cross, E., MirzA, A. B., Hayat, K., Kallue, A., and Yang, Y. Y. (1967). Height, weight, and skin-fold thickness. Data collected during a survey of rural and urban populations of West Pakistan. Amer. J. clin. Nutr., 20, 694.

WALLER, R. E., and BROOKs, A. G. F. (1972). Heights and weights of men visiting a public health exhibition. Brit. J. prev. soc. Med., 26, 180.

APPENDIX A

SMOKING HABITS BY AGE AND SOCIAL CLASS (PORT TALBOT AND EBBW VALE)

\begin{tabular}{|c|c|c|c|c|c|c|c|c|}
\hline \multirow[b]{2}{*}{ Social Class } & \multirow{2}{*}{\multicolumn{2}{|c|}{ Smoking Category }} & \multicolumn{5}{|c|}{ Age Group } & \multirow{2}{*}{$\begin{array}{l}\text { Standardized } \\
\text { for Age* }\end{array}$} \\
\hline & & & $20-24$ & $25-34$ & $35-44$ & $45-54$ & $55-64$ & \\
\hline \multirow[t]{2}{*}{ I and II } & $\begin{array}{l}\text { Never smoked } \\
\text { Ex-smoker } \\
\text { Smoker . }\end{array}$ & $\begin{array}{l}\cdots \\
\cdots\end{array}$ & $\begin{array}{r}35 \cdot 3 \\
9 \cdot 2 \\
55 \cdot 5\end{array}$ & $\begin{array}{l}33 \cdot 6 \\
13 \cdot 2 \\
53 \cdot 2\end{array}$ & $\begin{array}{c}\% \\
22 \cdot 3 \\
21 \cdot 3 \\
56 \cdot 4\end{array}$ & $\begin{array}{l}11 \cdot 2 \\
21 \cdot 9 \\
67 \cdot 0\end{array}$ & $\begin{array}{l}11 \cdot 8 \\
17 \cdot 3 \\
70 \cdot 9\end{array}$ & $\begin{array}{l}21 \cdot 3 \\
18 \cdot 1 \\
60 \cdot 6\end{array}$ \\
\hline & All categories & . & $\begin{array}{l}100 \\
(130)^{* * *}\end{array}$ & $\begin{array}{l}100 \\
(333)\end{array}$ & $\begin{array}{c}100 \\
(376)\end{array}$ & $\begin{array}{l}100 \\
(215)\end{array}$ & $\begin{array}{l}100 \\
(110)\end{array}$ & 100 \\
\hline \multirow[t]{2}{*}{ III } & $\begin{array}{l}\text { Never smoked } \\
\text { Ex-smoker } \\
\text { Smoker ... }\end{array}$ & $\begin{array}{l}. \\
\cdots\end{array}$ & $\begin{array}{l}41 \cdot 0 \\
13 \cdot 2 \\
45 \cdot 8\end{array}$ & $\begin{array}{l}31 \cdot 1 \\
19 \cdot 5 \\
49 \cdot 4\end{array}$ & $\begin{array}{l}15 \cdot 3 \\
23 \cdot 1 \\
61 \cdot 6\end{array}$ & $\begin{array}{l}14 \cdot 0 \\
22 \cdot 3 \\
63 \cdot 7\end{array}$ & $\begin{array}{l}14 \cdot 9 \\
20 \cdot 6 \\
64 \cdot 5\end{array}$ & $\begin{array}{l}20 \cdot 3 \\
20 \cdot 9 \\
58 \cdot 7\end{array}$ \\
\hline & All categories & . & $\begin{array}{l}100 \\
(188)\end{array}$ & $\begin{array}{c}100 \\
(344)\end{array}$ & $\begin{array}{c}100 \\
(333)\end{array}$ & $\begin{array}{l}100 \\
(193)\end{array}$ & $\begin{array}{c}100 \\
(141)\end{array}$ & $99 \cdot 9$ \\
\hline \multirow[t]{2}{*}{ III } & $\begin{array}{l}\text { Never smoked } \\
\text { Ex-smoker } \\
\text { Smoker ... }\end{array}$ & $\begin{array}{l}\cdots \\
\cdots\end{array}$ & $\begin{array}{l}28 \cdot 9 \\
13 \cdot 4 \\
57 \cdot 7\end{array}$ & $\begin{array}{l}24 \cdot 6 \\
16 \cdot 5 \\
58 \cdot 9\end{array}$ & $\begin{array}{l}13 \cdot 5 \\
21 \cdot 4 \\
65 \cdot 1\end{array}$ & $\begin{array}{l}12 \cdot 2 \\
19 \cdot 5 \\
68 \cdot 3\end{array}$ & $\begin{array}{r}8 \cdot 6 \\
22 \cdot 4 \\
69 \cdot 0\end{array}$ & $\begin{array}{l}16 \cdot 0 \\
19 \cdot 4 \\
64 \cdot 6\end{array}$ \\
\hline & All categories & .. & $\begin{array}{l}100 \\
(610)\end{array}$ & $\begin{array}{c}100 \\
(1849)\end{array}$ & $\begin{array}{c}100 \\
(2800)\end{array}$ & $\begin{array}{c}100 \\
(2338)\end{array}$ & $\begin{array}{c}100 \\
(1310)\end{array}$ & 100 \\
\hline \multirow[t]{2}{*}{ IV } & $\begin{array}{l}\text { Never smoked } \\
\text { Ex-smoker } \\
\text { Smoker ... }\end{array}$ & $\begin{array}{l}\cdots \\
\cdots\end{array}$ & $\begin{array}{l}28 \cdot 6 \\
16 \cdot 1 \\
55 \cdot 3\end{array}$ & $\begin{array}{l}21 \cdot 5 \\
15.9 \\
62.6\end{array}$ & $\begin{array}{l}11 \cdot 7 \\
19.4 \\
68.9\end{array}$ & $\begin{array}{l}10 \cdot 8 \\
19 \cdot 9 \\
69 \cdot 3\end{array}$ & $\begin{array}{l}10 \cdot 2 \\
20 \cdot 5 \\
69 \cdot 3\end{array}$ & $\begin{array}{l}14 \cdot 7 \\
18 \cdot 7 \\
66 \cdot 6\end{array}$ \\
\hline & All categories & .. & $\begin{array}{l}100 \\
(112)\end{array}$ & $\begin{array}{c}100 \\
(678)\end{array}$ & $\begin{array}{c}100 \\
(1100)\end{array}$ & $\begin{array}{c}100 \\
(1142)\end{array}$ & $\begin{array}{c}100 \\
(831)\end{array}$ & 100 \\
\hline \multirow[t]{2}{*}{$\mathbf{v}$} & $\begin{array}{l}\text { Never smoked } \\
\text { Ex-smoker } \\
\text { Smoker ... }\end{array}$ & $\begin{array}{l}\cdots \\
\cdots\end{array}$ & $\begin{array}{l}21 \cdot 1 \\
12 \cdot 3 \\
66 \cdot 6\end{array}$ & $\begin{array}{l}17 \cdot 5 \\
14 \cdot 7 \\
67 \cdot 8\end{array}$ & $\begin{array}{l}13 \cdot 1 \\
17 \cdot 5 \\
69 \cdot 4\end{array}$ & $\begin{array}{l}12 \cdot 1 \\
14 \cdot 5 \\
73 \cdot 4\end{array}$ & $\begin{array}{r}7 \cdot 3 \\
15 \cdot 0 \\
77 \cdot 7\end{array}$ & $\begin{array}{l}13 \cdot 5 \\
15 \cdot 3 \\
71 \cdot 2\end{array}$ \\
\hline & All categories & .. & $\begin{array}{c}100 \\
(389)\end{array}$ & $\begin{array}{l}100 \\
(607)\end{array}$ & $\begin{array}{l}100 \\
(633)\end{array}$ & $\begin{array}{l}100 \\
(580)\end{array}$ & $\begin{array}{l}100 \\
(494)\end{array}$ & 100 \\
\hline
\end{tabular}

In this column the age specific percentages have been weighted by the overall distribution. **No. of men. 
APPENDIX B

MEAN BODY WEIGHT (lb) ADJUSTED TO A HEIGHT OF 68 in $(173 \mathrm{~cm})$ BY SOCIAL CLASS, SMOKING HABITS, AND AGE

\begin{tabular}{|c|c|c|c|c|c|c|c|c|}
\hline \multirow[b]{2}{*}{ Social Class } & \multirow{2}{*}{\multicolumn{2}{|c|}{ Smoking Category }} & \multicolumn{5}{|c|}{ Age Group } & \multirow{2}{*}{$\begin{array}{c}\text { Age } \\
\text { Standardizec } \\
\text { Weight* }\end{array}$} \\
\hline & & & $20-24$ & $25-34$ & $35-44$ & $45-54$ & $55-64$ & \\
\hline \multirow[t]{2}{*}{ I and II } & $\begin{array}{l}\text { Never smoked } \\
\text { Ex-smoker } \\
\text { Smoker . . }\end{array}$ & $\begin{array}{l}\ldots \\
\cdots\end{array}$ & $\begin{array}{l}164 \\
152 \\
157\end{array}$ & $\begin{array}{l}171 \\
171 \\
166\end{array}$ & $\begin{array}{l}176 \\
178 \\
171\end{array}$ & $\begin{array}{l}181 \\
174 \\
170\end{array}$ & $\begin{array}{l}178 \\
169 \\
170\end{array}$ & $\begin{array}{l}175 \cdot 5 \\
172 \cdot 0 \\
168 \cdot 4\end{array}$ \\
\hline & Difference & $\cdots$ & 7 & 5 & 5 & 11 & 8 & $7 \cdot 1$ \\
\hline \multirow[t]{2}{*}{ Non-manual } & $\begin{array}{l}\text { Never smoked } \\
\text { Ex-smoker } \\
\text { Smoker . }\end{array}$ & $\begin{array}{l}\ddot{*} \\
\ddot{x}\end{array}$ & $\begin{array}{l}153 \\
154 \\
159\end{array}$ & $\begin{array}{l}169 \\
170 \\
163\end{array}$ & $\begin{array}{l}177 \\
179 \\
164\end{array}$ & $\begin{array}{l}180 \\
181 \\
167\end{array}$ & $\begin{array}{l}185 \\
170 \\
165\end{array}$ & $\begin{array}{l}175 \cdot 4 \\
174 \cdot 1 \\
164 \cdot 3\end{array}$ \\
\hline & Difference & . & -6 & 6 & 13 & 13 & 20 & $11 \cdot 1$ \\
\hline \multirow[t]{2}{*}{ Manual } & $\begin{array}{l}\text { Never smoked } \\
\text { Ex-smoker } \\
\text { Smoker ... }\end{array}$ & $\begin{array}{l}. \\
\cdots \\
\cdots\end{array}$ & $\begin{array}{l}161 \\
164 \\
158\end{array}$ & $\begin{array}{l}174 \\
177 \\
169\end{array}$ & $\begin{array}{l}184 \\
180 \\
171\end{array}$ & $\begin{array}{l}184 \\
181 \\
172\end{array}$ & $\begin{array}{l}183 \\
181 \\
168\end{array}$ & $\begin{array}{l}179 \cdot 9 \\
178 \cdot 5 \\
169 \cdot 3\end{array}$ \\
\hline & Difference & .. & 3 & 5 & 13 & 12 & 15 & $10 \cdot 6$ \\
\hline \multirow[t]{2}{*}{ IV } & $\begin{array}{l}\text { Never smoked } \\
\text { Ex-smoker } \\
\text { Smoker ... }\end{array}$ & $\begin{array}{l}\ddot{ } \\
\ddot{*}\end{array}$ & $\begin{array}{l}163 \\
167 \\
160\end{array}$ & $\begin{array}{l}178 \\
173 \\
166\end{array}$ & $\begin{array}{l}182 \\
176 \\
170\end{array}$ & $\begin{array}{l}183 \\
181 \\
171\end{array}$ & $\begin{array}{l}185 \\
180 \\
168\end{array}$ & $\begin{array}{l}180 \cdot 4 \\
176 \cdot 5 \\
168 \cdot 3\end{array}$ \\
\hline & Difference & . & 3 & 12 & 12 & 12 & 17 & $12 \cdot 1$ \\
\hline \multirow[t]{2}{*}{$\mathbf{v}$} & $\begin{array}{l}\text { Never smoked } \\
\text { Ex-smoker } \\
\text { Smoker . }\end{array}$ & $\begin{array}{l}\ddot{.} \\
\ddot{*}\end{array}$ & $\begin{array}{l}164 \\
158 \\
156\end{array}$ & $\begin{array}{l}170 \\
173 \\
164\end{array}$ & $\begin{array}{l}182 \\
179 \\
166\end{array}$ & $\begin{array}{l}187 \\
183 \\
167\end{array}$ & $\begin{array}{l}176 \\
177 \\
165\end{array}$ & $\begin{array}{l}178 \cdot 3 \\
176 \cdot 7 \\
164 \cdot 9\end{array}$ \\
\hline & Difference & .. & 8 & 6 & 16 & 20 & 11 & $13 \cdot 4$ \\
\hline
\end{tabular}

*In this column, age specific mean body weights have been weighted by overall age distribution. 